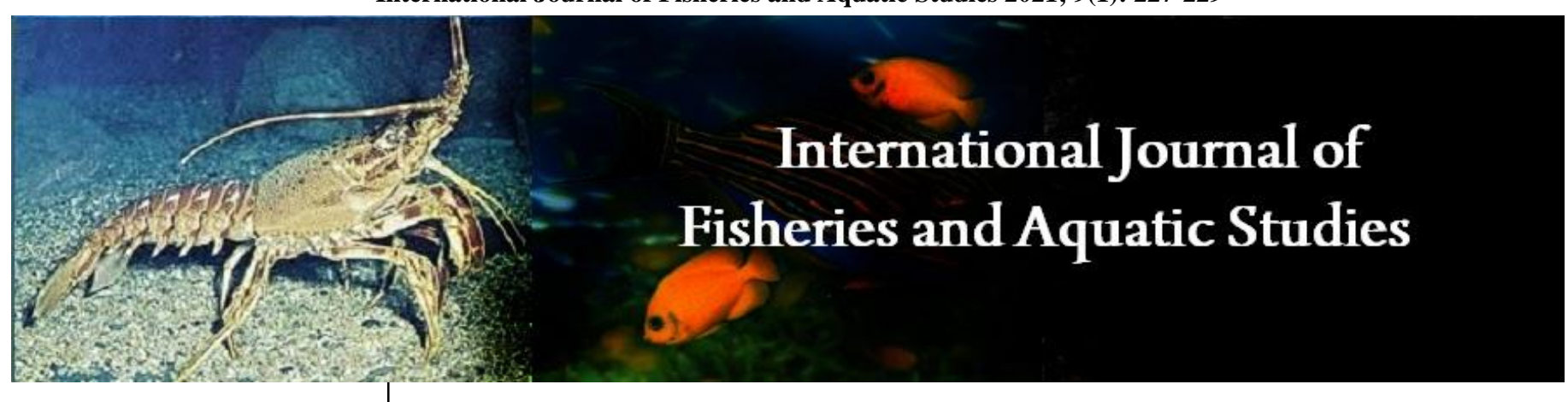

E-ISSN: 2347-5129

P-ISSN: 2394-0506

(ICV-Poland) Impact Value: 5.62

(GIF) Impact Factor: 0.549

IJFAS 2021; 9(1): 227-229

(C) 2021 IJFAS

www.fisheriesjournal.com

Received: 19-11-2020

Accepted: 21-12-2020

Benjamin C Young

(1) National Fisheries Center,

Ministry of Environment, Water

\& Agriculture, Post Office Box

9612, Jeddah 21423, Kingdom of

Saudi Arabia

(2) Taiwan International

Cooperation and Development

Fund, Taipei 11047, Taiwan

Riyadh Hussain Alfaggeh

National Fisheries Center,

Ministry of Environment, Water

\& Agriculture, Post Office Box

9612, Jeddah 21423, Kingdom of

Saudi Arabia

Ibrahim Al Moutiri

National Fisheries Center,

Ministry of Environment, Water

\& Agriculture, Post Office Box

9612, Jeddah 21423, Kingdom of

Saudi Arabia

Asim Abdullah Barnawi

National Fisheries Center,

Ministry of Environment, Water

\& Agriculture, Post Office Box

9612, Jeddah 21423, Kingdom of

Saudi Arabia

Hosam Jamaan Alzheani

National Fisheries Center,

Ministry of Environment, Water

\& Agriculture, Post Office Box

9612, Jeddah 21423, Kingdom of Saudi Arabia

Corresponding Author:

Benjamin C Young

(1) National Fisheries Center,

Ministry of Environment, Water

\& Agriculture, Post Office Box

9612, Jeddah 21423, Kingdom of

Saudi Arabia

(2) Taiwan International

Cooperation and Development

Fund, Taipei 11047, Taiwan

\section{Effects of high stocking density on survival and growth of Sabaki tilapia Oreochromis spilurus}

\author{
Benjamin C Young, Riyadh Hussain Alfaggeh, Ibrahim Al Moutiri, Asim \\ Abdullah Barnawi and Hosam Jamaan Alzheani
}

DOI: https://doi.org/10.22271/fish.2021.v9.i1c.2407

\begin{abstract}
This study's main objective was to estimate the survival rate and growth performance of grow-out Sabaki tilapia (Oreochromis spilurus, Günther, 1894) at different high stocking density levels: 50, 100, 150, 200 and 250 fish per $\mathrm{m}^{3}$. The experiments were conducted in triplicate and monitored for survival rate and growth performance for an experimental period of 16 weeks. Results indicated that the survival rate was significantly different in higher stocking density groups. The growth performance was not significantly different in each group. Overall, the results indicate that the Sabaki tilapia farming is feasible in high stocking density conditions.
\end{abstract}

Keywords: Sabaki tilapia, aquaculture, Saudi Arabia, high stocking density

\section{Introduction}

In the Kingdom of Saudi Arabia (henceforth, Saudi Arabia), fish farming is becoming essential for aquaculture in sustainable economic development and food security. Moreover, because of the limitation of factor policies and natural environment, marine fish culture is more suitable than that of freshwater fish ${ }^{[1]}$.

Tilapias (Oreochromis spp.) are one of the most important fish species in the global aquaculture industry. Among the various tilapia species, the Sabaki tilapia (Oreochromis spilurus, Günther, 1894) is one of the unique and higher economic value species in the global tilapia aquaculture industry. Due to market demand and environmental factors, Saudi fisheries authority selected Sabaki tilapia to target the aquaculture development projects' species, while the commercial culture of Sabaki tilapia had not been developing in Saudi Arabia ${ }^{[2]}$.

Several studies suggested that in intensive aquaculture, the stocking density is an important factor that determines the economic viability of the production system ${ }^{[3-6]}$. Although several studies have examined biological conditions, such as growth and survival, of various freshwater tilapia species fry under different stocking densities ${ }^{[7-10]}$, there is a lack of related information for the marine tilapia species grow-out stage.

The objectives of this study were to assess the effects of stocking density on growth and survival of grow-out Sabaki tilapia.

\section{Materials and Methods}

\subsection{Experimental design}

The research was conducted from 20 August 2020 to 10 December 2020. The grow-out Sabaki tilapia directly collected from National Fisheries Center, Saudi Arabia. The average weight of Sabaki tilapia is $152.6 \pm 1.62 \mathrm{~g}$, the gender of tilapia is all male. Experiments were conducted in triplicate in 1000L fiber-reinforced plastic (FRP) tanks with 50, 100, 150, 200, and 250 fish per tank in the outdoor condition.

The fish were fed with manual feeding that control the time, frequency, and quantity of food. To avoid the occurrence of feeding competition. The daily feeding amount is $3 \%$ of total fish weight with feeding commercial feed ( $4 \mathrm{~mm}, 36 \%$ crude protein, and $4.0 \%$ crude fat).

Daily water exchange (200\%) and maintain the salinity (42\%). The temperature ranged from 25.3 to $32.0{ }^{\circ} \mathrm{C} ; \mathrm{pH}$ ranged from 7.27 to 7.30 , and dissolved oxygen (DO) ranged from 4.80 to 
$6.10 \mathrm{mg} / \mathrm{l}$ in the tanks. Fish was randomly sampled and measured at one-week intervals at :00-10:00 AM for body weight to the nearest $0.1 \mathrm{~g}$ in every tank. Percentage survival (\%) was determined as the number of survivors at the end of the experiment $\times 100 /$ number stocked initially. Specific growth rate (SGR) was determined as: SGR (\% body weight day-1) $=[(\ln (\mathrm{W} 2-\mathrm{W} 1)) \times 100] / \Delta \mathrm{t}$, where $\mathrm{W} 1=$ initial wet weight of fish at stocking, W2 = final wet weight of fish, $t=$ grow-out period. Feed conversion ratio (FCR) was determined as: feed given / fish weight gain.

\subsection{Statistical analyses}

The data were analyzed by PASW (Predictive Analytics Software, IBM, USA) 18.0, using one-way ANOVA and Duncan's multiple range test was carried out for post hoc comparison of the mean. A significance level of $P<0.05$ was applied.

\section{Results}

The results of the experiment indicated that the maximum stocking density endured for the survival of Sabaki tilapia farming is $150 \mathrm{fish} / \mathrm{m}^{3}$. The survival rate was significantly different among different stocking density throughout the experiment, especially in the 250 fish group which showed lower survival rate than other groups (Table 1). However. The growth performance was not significantly different between each group (Table 1).

Table 1: The survival rate and growth performance of Sabaki tilapia at different stocking density

\begin{tabular}{|c|c|c|c|}
\hline $\begin{array}{c}\text { Stocking } \\
\text { density }\end{array}$ & $\begin{array}{c}\text { Survival } \\
\text { rate }(\%)\end{array}$ & SGR & FCR \\
\hline 50 & $94 \pm 1.8^{\mathrm{a}}$ & $0.93 \pm 0.06^{\mathrm{a}}$ & $1.45 \pm 0.17^{\mathrm{a}}$ \\
\hline 100 & $96 \pm 0.1^{\mathrm{a}}$ & $0.93 \pm 0.15^{\mathrm{a}}$ & $1.45 \pm 0.06^{\mathrm{a}}$ \\
\hline 150 & $95.33 \pm 1.6^{\mathrm{a}}$ & $0.93 \pm 0.1^{\mathrm{a}}$ & $1.46 \pm 0.15^{\mathrm{a}}$ \\
\hline 200 & $92 \pm 2.1^{\mathrm{b}}$ & $0.92 \pm 0.12^{\mathrm{a}}$ & $1.45 \pm 0.15^{\mathrm{a}}$ \\
\hline 250 & $76.1 \pm 1.3^{\mathrm{c}}$ & $0.92 \pm 0.01^{\mathrm{a}}$ & $1.47 \pm 0.07^{\mathrm{a}}$ \\
\hline
\end{tabular}

Different letters at each column indicate a significant difference $(P<$ $0.05)$

\section{Discussion and Conclusion}

Our results indicate that stocking density of $50 \sim 150 \mathrm{fish} / \mathrm{m}^{3}$ is suitable for Sabaki tilapia farming. Furthermore, Ridha ${ }^{[9]}$ and Abdel-Tawwab ${ }^{[11]}$ showed that the survival rate of freshwater tilapia farming was approximately $97.4 \%-100 \%$ in groups of 125 200 fish $/ \mathrm{m}^{3}$. Under conditions of increased stocking density, we noticed that the survival rate of Sabaki tilapia was $76.1 \%$.

Moreover, Yi et al. ${ }^{[12]}$, Shoemaker et al. ${ }^{[13]}$, and Gibtan [14] suggested that farming production facilities were affected the survival rate and growth performance. Our experiments were ongoing in the outdoor system with high daily water exchange and higher live food resources. Hence, our results' survival rate and the growth performance were not significantly different from finding from previous research in indoor or recirculating aquaculture systems.

Our results indicated that the survival rate and growth performance of the Sabaki tilapia were not significantly different from finding from previous research of freshwater tilapia farming ${ }^{[7-12]}$.

Besides, because of the unique farming environment in Saudi Arabia, the farming environment was under high salinity and temperature in the producing period ${ }^{[1]}$. Notably, the bacterial infection continually emerges in the winter season. These factors caused a lower survival rate in higher stocking density.
In summary, our results indicate that Sabaki tilapia farming is feasible in high stocking density conditions. The growth performance showed no significant difference under high stocking density conditions. These results indicate that the best stocking density during the survival and growth of Sabaki tilapia farming is $150 \mathrm{fish} / \mathrm{m} 3$. These results can be utilized to inform related research and aquacultural development in marine tilapia farming.

\section{Acknowledgments}

The authors thank the National Fisheries Center for providing all material.

\section{Competing Interests Statement}

The authors have no competing interests to declare.

\section{References}

1. Young BC, Shabi AA, Hajuji TT, Alfaggeh RH, Al Moutiri I. Status of Sabaki Tilapia Aquaculture in the Kingdom of Saudi Arabia. Advances Oceanography \& Marine Biology 2020;2:1-2.

2. Young BC, Alfaggeh RH, Al Moutiri I. Potential new species in the Kingdom of Saudi Arabia: Sabaki tilapia (Oreochromis spilurus). Aquaculture Asia 2020;24:3-5.

3. Huang WB, Chiu TS. Effects of stocking density on survival, growth, size variation, and production of Tilapia fry. Aquaculture Research 1997;28(3):165-173.

4. Hashim R, Chong AS, Fatan NA, Layman N, Ali A. Production of hybrid red tilapia, $\times O$. niloticus, at varying stocking densities in portable canvas tanks. Journal of Applied Aquaculture 2002;12(3):1-12.

5. Abou Y, Fiogbé ED, Micha JC. Effects of stocking density on growth, yield and profitability of farming Nile tilapia, Oreochromis niloticus L., fed Azolla diet, in earthen ponds. Aquaculture Research 2007;38(6):595604.

6. Szkudlarek M, Zakęś Z. Effect of stocking density on survival and growth performance of pikeperch, Sander lucioperca (L.), larvae under controlled conditions. Aquaculture International 2007;15(1):67-81.

7. Suresh AV, Lin CK. Effect of stocking density on water quality and production of red tilapia in a recirculated water system. Aquacultural Engineering 1992;11(1):1-22.

8. El-Sayed AFM. Effects of stocking density and feeding levels on growth and feed efficiency of Nile tilapia (Oreochromis niloticus L.) fry. Aquaculture Research 2002;33(8):621-626.

9. Ridha MT. Comparative study of growth performance of three strains of Nile tilapia, Oreochromis niloticus, L. at two stocking densities. Aquaculture research 2006;37(2):172-179.

10. Ferdous Z, Masum MA, Ali MM. Influence of stocking density on growth performance and survival of monosex tilapia (Oreochromis niloticus) fry. International Journal of Research in Fisheries and Aquaculture 2014;4(2):99103.

11. Abdel-Tawwab M. Effects of dietary protein levels and rearing density on growth performance and stress response of Nile tilapia, Oreochromis niloticus (L.). International Aquatic Research 2012;4(1):3.

12. Yi Y, Lin CK, Diana JS. Influence of Nile tilapia (Oreochromis niloticus) stocking density in cages on their growth and yield in cages and in ponds containing the cages. Aquaculture 1996;146(3-4):205-215. 
13. Shoemaker CA, Evans JJ, Klesius PH. Density and dose: factors affecting mortality of Streptococcus iniae infected tilapia (Oreochromis niloticus). Aquaculture 2000; 188(3, 4):229-235

14. Gibtan A, Getahun A, Mengistou S. Effect of stocking density on the growth performance and yield of Nile tilapia [Oreochromis niloticus (L., 1758)] in a cage culture system in Lake Kuriftu, Ethiopia. Aquaculture Research 2008;39(13):1450-1460. 